\title{
Periplasmic expression of a restriction endonuclease in Escherichia coli and its effect on the antiviral activity of the host
}

\author{
Karolina Wilkowska, Monika Targonska, Agata Smarz and Marian Sektas ${ }^{\natural}$ \\ Department of Microbiology, University of Gdansk, Gdańsk, Poland
}

One possible mechanism preventing phage infection of the bacterial cells is related to the presence of an effective restriction-modification system (R-M) which allows restriction of the invading DNA. However, there are some limitations to the absolute restriction of foreign DNA. Since there is a serious conflict between increase in the restriction-modification genes expression level and cell viability, we examined the antiviral effect of EcoRI restriction endonuclease after its translocation to the periplasmic space of the cell. We assumed that such reconstructed R-M system could be able to degrade foreign DNA at the stage of its passage through the cell envelope of Gram-negative bacteria, before its penetration into the bacterial cytoplasm. The Tat secretion pathway of Escherichia coli was used to export R.EcoRI fused to the TorA leader peptide across the cytoplasmic membrane. However, although we observed a huge accumulation of the TorAss-R.EcoRI pre-protein in the cytoplasm the Tat system did not provide an efficient transport across the cytoplasmic membrane. Moreover, our data strongly suggest that endonuclease cannot function under the conditions prevailing in periplasmic space, therefore, the transported endonuclease could not contribute to an increase in restriction properties of the host.

Key words: Tat secretion, EcoRI endonuclease, TorA, DsbA, periplasmic expression, DNA restriction

Received: 15 November, 2018, revised: 28 January, 2019; accepted: 31 Januray, 2019; available on-line: 15 February, 2019

$\square$ e-mail: marian.sektas@biol.ug.edu.pl

Abbreviations: DsbA, thiol disulfide oxidoreductase; GFP, green fluorescent protein; SRP, signal recognition particle pathway; Tat, twin-arginine translocation system; TorA, trimethylamide $\mathrm{N}$-oxide reductase

Acknowledgement of the Financial Support: This work was supported by the Ministry of Science and Higher Education (530-L135D584-18).

\section{INTRODUCTION}

Many strains of Escherichia coli (E. coli) and other Gram-negative bacteria are used for the production of heterologous proteins of vital practical importance and measurable commercial market. In any biotech venture, to make it reproducible and cost-effective, in addition to the optimization of culture growth conditions and to control of target gene expression it is necessary to create a proper protection that prevents cell lysis. Virulent bacteriophages are one of the major risks when carrying bacterial cultivation in the laboratory and in industrial processes. Bacteriophages are able to induce cell lysis even in large scale cultures. Restriction-modification systems (R-M) protect bacterial cells against the invasion of viral DNA (Makarova et al., 2013). They exist in almost all bacterial strains and consist of two types of enzymes: a restriction endonuclease and a methyltransferase. The endonuclease specifically recognizes target nucleotide sequence and cuts it while akin DNA methyltransferase protects the sequence from being cut through methylation of specific bases. This allows the bacteria to survive in the hostile phage-abundant environment. Bacteriophages have several mechanisms to counteract the restriction of their own DNA in the bacterial cell at the early stages of infection (Tock and Dryden, 2005; Labrie et al., 2010; Samson et al., 2013). In the natural environment, restriction of foreign DNA reduces the possibility of viral infections by 2-3 orders of magnitude but does not eliminate them completely.

The aim of this project was to evaluate whether the transfer of the process of foreign DNA restriction into the bacterial periplasm could be effective in degradation of the invading DNA. A model EcoRI restriction endonuclease was translocated to the periplasmic space by the Tat (twin-arginine translocation) secretion system (Bogsch et al., 1998; Santini et al., 1998; Sargent et al., 1998) utilizing native and cleavable E. coli signal sequences from pre-trimethylamine $\mathrm{N}$-oxide (TMAO) reductase TorA (Mejean et al., 1994; Santini et al., 1998). Cells expression the hybrid proteins were challenged by $\lambda_{\text {vir }}$ bacteriophage infection.

\section{MATERIALS AND METHODS}

Bacterial strains and plasmids. E. coli $\mathrm{K}-12$ strains used in this work included DH5 $\alpha\left(\mathrm{F}^{-} \lambda^{-}\right.$end $A 1 \operatorname{glnV} 44$ thi-1 recA1 relA1 gyrA96 deoR nирG $\Phi 80$ dlacZ $\triangle M 15$ $\Delta$ (lacZYA-argF)U169, hsdR17( $\left.\mathrm{r}_{\mathrm{K}}-\mathrm{m}_{\mathrm{K}}{ }^{+}\right) \quad$ (New England Biolabs) for the recovery and propagation of the recombinant plasmids, and as a source of torA (TMAO reductase) signal sequence; ER1992 ( $\mathrm{F}^{-} \Delta$ (argF-lac)U169 supE44 e14- dinD1::Mu dI1734 (Kan $\left.{ }^{\mathrm{R}}, \mathrm{Lac}^{+}\right)$rfbD1? relA1? endA1 spoT1? thi-1 $\Delta$ (morC-mrr)114::IS10) (Fomenkov et al., 1994) (New England Biolabs) and DH10B (FmorA $\Delta$ (mrr-hsdRMS-morBC) D80lac Z $\Delta \mathrm{M} 15 \Delta$ lacX74 recA1 endA1 araD139 $\Delta$ (ara leu) 7697 gal galK rpsL nupG $\left.\lambda^{-}\right)$ (Grant et al., 1990) both used in phage restriction assays. Moreover, Tat strains: DADE (as MC4100 $\triangle$ tat $A B C D$ $\Delta$ tatE, (Wexler et al., 2000) and B1LK0 (AtatC, (Sargent et al., 1998) which were gifts from prof. T. Palmer (University of Dundee) and the periplasmic protease deficient strain HM140 ( $\mathrm{F}^{-} \Delta$ lacX74 galE galK thi rpsL $\Delta$ pho A degP. ptr ompT eda tsp rpoH15 $\mathrm{Str}^{\mathrm{R}} \mathrm{Km}^{\mathrm{R}} \mathrm{Tet}^{\mathrm{R}} \mathrm{Cm}^{\mathrm{R}}$, (Meerman and Georgiou, 1994) were used as the controls of Tatdependent fusion gene expression. E. coli SOS-reporter strains MP060 (MG1655 $\Delta$ attHK022::P sulA $_{y}$ fP) and MP064 (MP060 $\Delta \operatorname{rec} A$ ) (Pleška et al., 2016) were used for selfrestriction evaluation. E. coli cells were grown in LB me- 
dia when necessary supplemented with antibiotics at the following concentrations: ampicillin (Ap) at $50 \mu \mathrm{g} / \mathrm{ml}$, chloramphenicol $(\mathrm{Cm})$ at $12.5 \mu \mathrm{g} / \mathrm{ml}$, kanamycin $(\mathrm{Km})$ at $15 \mu \mathrm{g} / \mathrm{ml}$ and tetracycline (Tc) at $15 \mu \mathrm{g} / \mathrm{ml}$. L-arabinose (Sigma) and isopropyl $\beta$-D-1-thiogalactopyranoside (IPTG, Sigma) were used as indicated in the experiments. Plasmids (Supplementary Table 1 at https://ojs.ptbioch. edu.pl/index.php/abp) were introduced to the cells by a standard chemical procedure (Sambrook, 1989).

ecoRIR fusion construction. Construction of ecoRIR endonuclease gene in fusion with trimethylamine $N$ oxide reductase TorA signal peptide (44 aa N-terminal, with -AQAAR remaining after the cleavage at the fusion site (Mejean et al., 1994; Thomas et al., 2001) allowed secretion of the resulting product to the periplasmic space. In order to test the functionality of the secretion and/or posttranslational modification of such a hybrid first, we constructed the tor $A^{\prime}$-ecoRIR'$g / p$ fusion gene under control of an arabinose-inducible $\mathrm{P}_{\text {araBAD }}$ promoter of $\mathrm{pBAD} 24$ plasmid vector (Guzman et al., 1995). Using specific primers for the leader sequence of the tor $A$ gene, torA.for and torA.rev (Supplementary Table 1 at https://ojs.ptbioch.edu.pl/index. php/abp), the PCR products (145 bp) with NcoI-SalII restriction sites on their ends were obtained and then cloned into the corresponding sites of the pBAD24, resulting in pBadT. Next, proximal fragment of the ecoRIR gene was PCR-amplified using REcoRIBgl2 and P1457 primers and pIM-RM plasmid as a template (Mruk et al., 2011), then cut with BglII and HindIII (204 bp), and cloned into the BglII and HindIII sites of the pBadT. Thus, obtained vector was named pBadTR' and contained a fragment spanning 2-70 aa of the R.EcoRI protein $\mathrm{N}$ terminus. Then, PCR was used to generate an Aequorea victoria gfp F64L/S65T double mutant gene using Gfpup and Gfpdown primers and pGreenTIR vector as a template (Miller and Lindow, 1997). The resulting $g f p$ gene was flanked by HindIII restriction sites with a synonymous serine codon mutation at the 2 nd position, and was then cloned into the HindIII site of pBadTR'. The final construct was named pBadTR'G (Fig. 2). Plasmid pBadTR carrying the complete sequence of the ecoRIR gene in fusion with torAss was obtained by cloning a PCR-generated DNA product (by using RecoBgl2 and RecoHind primers) cut by HindIII (641 bp) and inserted downstream of a proximal part of ecoRIR' gene in pBadTR' to recreate the whole gene. Taq DNA polymerase (Fermentas) was used in all PCR reactions.

Analogously, $d s b A^{\prime}$-ecoRIRM under control of arabinose promoter was constructed in three steps. First, two partially overlapping $58 \mathrm{nt}$ oligos coding $d s b A$ leader sequence (22 codons) were annealed and filled in by polymerase DNA I Klenow fragment. Resulted 86-bp dsDNA fragment was restricted with EcoRI and Sall and ligated to the similar sites of pBAD24. Then, BglII-HindII fragment of the ecoRIR gene from pBadTR' was subcloned. Finally, HindIII-HindIII fragment with 'ecoRIRecoRIM from pBadTRM was joined, resulting in plasmid pBADdsbRM (Supplementary Table 1 at https://ojs.ptbioch.edu.pl/index.php/abp).

The pSALectEcoRI vector carrying the ecoRIR translational fusion gene between $\mathrm{N}$-terminal tor $A$ leader and C-terminal $\beta$-lactamase fusion reporter (bla gene) for periplasmic transport via the Tat secretion system was constructed by cutting the pSalectDmdNK+1 (Lutz et al., 2002) with NdeI/SpeI and insertion of a PCR-created ecoRIR endonuclease gene. The expression of fusion gene was induced with $1 \mathrm{mM}$ IPTG at $37^{\circ} \mathrm{C}$ for $1 \mathrm{~h}$. All fusions were verified by DNA sequencing.

Preparation of subcellular fractions. Overnight culture of $\mathrm{DH} 5 \alpha$ carrying an appropriate plasmid (pBadTR'G or others) was diluted with fresh LB medium supplemented with ampicillin. Cell pellet obtained from $1.5 \mathrm{ml}$ of culture was collected and suspended in $400 \mu \mathrm{l}$ of a sucrose buffer to induce osmotic shock $(20 \%$ sucrose, $200 \mathrm{mM}$ Tris-HCl (pH 7.6), 1 mM EDTA). Fractionation was done according to the method described by (Harrison et al., 1997). The spheroplast pellet (cytoplasmic fraction) was suspended in $120 \mu$ l of ice water and frozen. Only $20 \mu \mathrm{l}$ of the total volume was applied to each well of the gel for analysis. The supernatant (periplasmic fraction) was concentrated 2 -fold by evaporation under mild conditions, before being subjected to electrophoresis. For endonuclease activity determination $0.4 \mu \mathrm{g}$ of $\lambda$ DNA was digested for 1.5 hour with $3 \mu \mathrm{l}$ of each cell extract.

Ion-exchange protein fractionation. The R.EcoRI and ssTorA-R.EcoRI protein lysates obtained from $\mathrm{DH} 5 \alpha$ strains carrying $\mathrm{pBadTR}$, were separated by ion exchange chromatography. Bacterial pellet obtained from $100 \mathrm{ml}$ culture after $2 \mathrm{~h}$ of $0.03 \%$ L-arabinose induction was suspended in $6 \mathrm{ml}$ of buffer $\mathrm{S}\left(10 \mathrm{mM} \mathrm{KPO}_{4} \mathrm{pH}\right.$ 7.4, $20 \mathrm{mM} \mathrm{KCl}, 1 \mathrm{mM}$ EDTA, $10 \mathrm{mM}$ 2-mercaptoethanol, $5 \%$ glycerol, containing $0.1 \mathrm{mM}$ phenyl-methyl-sulfonyl-fluoride (PMSF) as a protease inhibitor) and disrupted by sonication at $4{ }^{\circ} \mathrm{C}$ in $60-10-s$ bursts. The sonicated cells were centrifuged at $14,000 \mathrm{rpm}$ for $30 \mathrm{~min}$. The resulting supernatant was applied to a phosphocellulose P11 column (Whatman) $(2.5 \times 2.5 \mathrm{~cm})$ equilibrated with buffer $\mathrm{S}$ without PMSF. The column was washed with $200 \mathrm{ml}$ of buffer $\mathrm{S}$ and the enzymes were eluted with a $100 \mathrm{ml}$ linear gradient ranging from $20 \mathrm{mM}$ to $1000 \mathrm{mM} \mathrm{KCl}$ in the same buffer. $1.75 \mathrm{ml}$ fractions were collected and assayed for restriction activity and assessed to determine protein concentration.

SDS-PAGE and western blot analysis. Proteins were analyzed after 10\% SDS-PAG electrophoresis by Coomassie Blue staining or were transferred onto a nitrocellulose membrane. The lysates were diluted in electrophoresis sample buffer and heated at $95^{\circ} \mathrm{C}$ for $5 \mathrm{~min}$. Electrotransfer was conducted at room temperature overnight at $20 \mathrm{~V}$ in Tris-glycine buffer (25 mM Tris/192 $\mathrm{mM}$ glycine, $\mathrm{pH}$ 8.3). The membrane was blocked in a TBS buffer ( $25 \mathrm{mM}$ Tris- $\mathrm{HCl} \mathrm{pH} 7.8,0.5 \mathrm{M} \mathrm{NaCl})$ with $3 \%$ skimmed milk, and then incubated with rabbit polyclonal anti-R.EcoRI and anti-M.EcoRI antibodies (kindly provided by I. Kobayashi, University of Tokyo). Anti-R. EcoRI and anti-M.EcoRI sera were diluted 1:4000 before use. Then, the nitrocellulose membrane was washed with TBS with 3\% milk and incubated with anti-rabbit IgG goat antibody conjugated to alkaline phosphatase (diluted 1:20000, Sigma) or anti-rabbit goat IgG conjugated to horseradish peroxidase (diluted 1:80000, Sigma). To detect specific targets the substrates for alkaline phosphatase (only in experiment illustrated in Supplementary Fig. 2 at https://ojs.ptbioch.edu.pl/index.php/ abp) nitro blue tetrazolium/5-bromo-4-chloro-3-indolyl phosphate (NBT/BCIP) were used (Fermentas). To detect the peroxidase activity, a Pierce ECL Plus Substrate (Thermo Scientific) was used. Nitrocellulose membrane was exposed to X-ray film to capture chemiluminescent signal.

For detection of the GFP protein, a mouse anti-GFP (Santa Cruz Biotechnology, dilution 1:1000) primary antibody was used, followed by incubation with an anti- 
mouse antibody conjugated to horseradish peroxidase (Sigma, 1:150000 dilution of $1 \mathrm{mg} / \mathrm{ml}$ stock solution).

Phage restriction assays. The restriction activity of $E$. coli cells carrying the ecoRIR genes was measured by determination of the plating efficiency of the $\lambda \mathrm{b} 2$ vir phage (Kellenberger et al., 1960). All tests were performed with freshly transformed cells. Serial dilutions of $\lambda \mathrm{b} 2$ vir phage in TM buffer $(10 \mathrm{mM} \mathrm{MgSO}, 100 \mathrm{mM} \mathrm{NaCl})$ were prepared ranging from 1 to $10^{8}$. Qualitative assay: $4 \mathrm{ml}$ of top agar preheated to $45^{\circ} \mathrm{C}$ with $300 \mu$ l bacterial culture was poured on LA plates and allowed to set for $15 \mathrm{~min}$. Then, $10-\mu \mathrm{l}$ spots of the phage dilutions were applied with following overnight incubation at $37^{\circ} \mathrm{C}$. Quantitative assay: mixtures of appropriate phage dilutions $(100 \mu \mathrm{l})$ and host bacteria $(300 \mu \mathrm{l})$ were incubated for $15 \mathrm{~min}$ at room temperature and then $4 \mathrm{ml}$ of top agar was added and the whole mixture was poured onto the LA plate and incubated overnight at $37^{\circ} \mathrm{C}$. The efficiency of plaque formation was calculated as a quotient of plaque-forming units obtained with cells carrying the tested plasmid and plaque-forming units obtained with a restriction-negative strain.

\section{RESULTS AND DISCUSSION}

\section{The rationale of the project}

The key factor ensuring effectiveness of the invading DNA restriction is the shift of the balance between DNA methyltransferase and its cognate endonuclease towards the restriction activity. As it was reported previously, using an immunocytochemical microscopy technique EcoRI endonuclease molecules were localized predominantly within the envelope part of E. coli cells, including the periplasmic space (Kohring \& Mayer, 1987). Similarly, HsdR subunit of the heteromultimeric EcoKI type I R-M enzyme was found to be associated with the cytoplasmic membrane, having access to the periplasmic space (Holubova et al., 2000). Thus, it could be assumed that periplasmic localization is well-adapted for the restriction of foreign DNA. Apart from this, there is still an open question whether the restriction endonuclease could be active in the periplasm.

We first attempted to construct an E. coli strain with higher resistance to viral infection using an arabinoseinducible EcoRI R-M system on pBAD24 plasmid (Guzman et al., 1995) (Fig. 1, Supplementary Table 1 at https://ojs.ptbioch.edu.pl/index.php/abp). However, overexpression of the R.EcoRI led to exposure of the chromosome to restriction cleavage, as was shown by

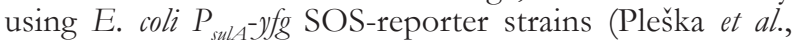
2016) (Supplementary Fig. 1 at https://ojs.ptbioch.edu. $\mathrm{pl} /$ index.php/abp). We continued to use a convenient tool of expression control of the EcoRI R-M genes by $\mathrm{P}_{\text {araBAD }}$ promoter/araC regulatory unit of $\mathrm{pBAD} 24$ in order to test a possibility to export a fraction of the endonuclease enzyme (and, in fact, to relocate the whole process of DNA restriction) into the bacterial periplasm, expecting its higher effectiveness in milieu free of DNA methylation. To make the optimal choice of an appropriate combination of promoter and secretion pathways we decided to use the Tat-dependent secretion system which provides an interesting alternative among others because in this system only properly folded proteins are exported, which assures their activity also in the cytoplasm (DeLisa et al., 2002; Bruser, 2007). We used E. coli tor $A$ leader sequence which has a prominent potential to export many useful proteins

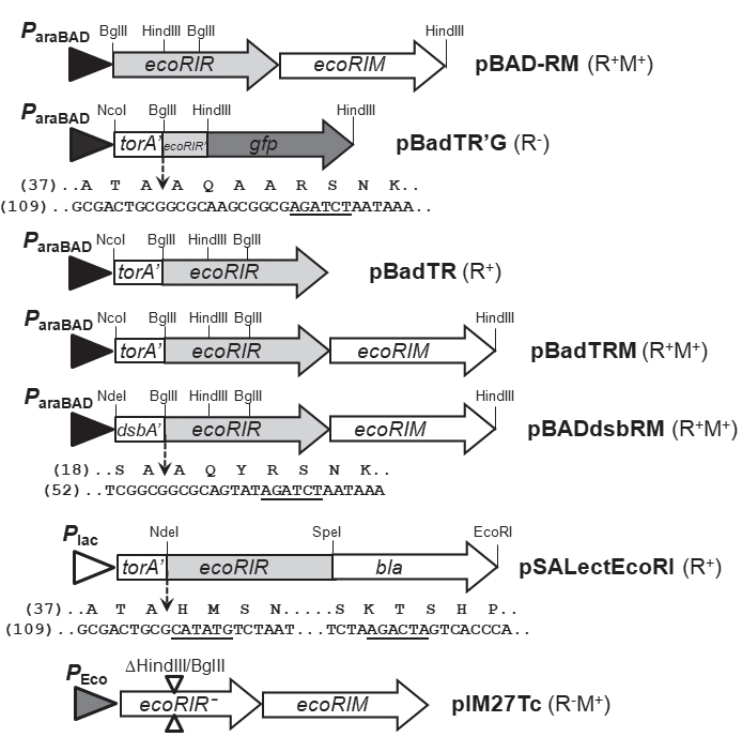

Figure 1. The scheme of the plasmid constructs key features. Set of EcoRI R-M expression vectors for the export of hybrid proteins to the periplasmic space via Tat secretion system: pBadTE'G for TorAss-R.EcoRI $\Delta_{71-277}$-GFP (pre-protein/mature - 39.1/34.5 kDa), pBadTRM for TorAss-R.EcoRI (35.7/31.2 kDa), and pSALectEcoRI for TorAss-R.EcoRI- $\beta$-lactamase $(64.5 / 60.3 \mathrm{kDa})$, or SRP secretion system: pBADdsbRM for DsbAss-R.EcoRI (33.7/31.7 kDa). In addition, amino-acid and nucleotide sequence of fusion junctions with SPase I cleavage sites (arrow) and Bglll and Spel restriction sites (underlined) are shown.

(Mergulhao et al., 2005; Matos et al., 2012). Since we used the arabinose-inducible $\mathrm{P}_{\mathrm{araBAD}}$ promoter, all the fusion constructs containing the ecoRIR gene with appropriate signal leader sequence together with ecoRIM gene were made as pBAD24 derivatives (Fig. 1, Supplementary Table 1 at https://ojs.ptbioch.edu.pl/index. php/abp). As the result the expression level of such modified endonuclease and its restriction effectiveness could be tested by measuring the efficiency of infection (EOP) by the virulent lambda phage.

\section{Tat-dependent export of R.EcoRI endonuclease/GFP reporter hybrid}

Next, we chose the twin-arginine translocation (Tat) system as the most useful and advantageous secretion pathway for correctly folded heterogenous proteins (DeLisa et al., 2002; Kudva et al., 2013). Transport across the cytoplasmic membrane to the periplasmic space requires an $\mathrm{N}$-terminal signal peptide which is recognized by membrane transport system consisting of TatA/E, TatB and TatC proteins (DeLisa et al., 2002). A wide variety of recombinant proteins were successfully targeted to periplasm using the TorA signal sequence (Bruser, 2007; Matos et al., 2012). So far, only one attempt of secretion of endonuclease to the periplasmic space and extracellular medium was reported (Toksoy et al., 1999; Toksoy et al., 2001). However, the efficient transport of the hybrid protein by the Sec general secretory pathway was detected after only 12-18 h of induction.

To examine the relative efficiency of the secretion and posttranslational periplasmic processing of TorAss-R. EcoRI hybrid, we initially constructed the tor $A^{\prime}-e c o R I^{\prime}-g / P$ fusion gene under arabinose-inducible $\mathrm{P}_{\text {araBAD }}$ promoter in the pBAD24 vector (Guzman et al., 1995) (Fig. 1). The GFP reporter protein is convenient to test the Tat system functionality and monitor the fate of the hybrid protein 

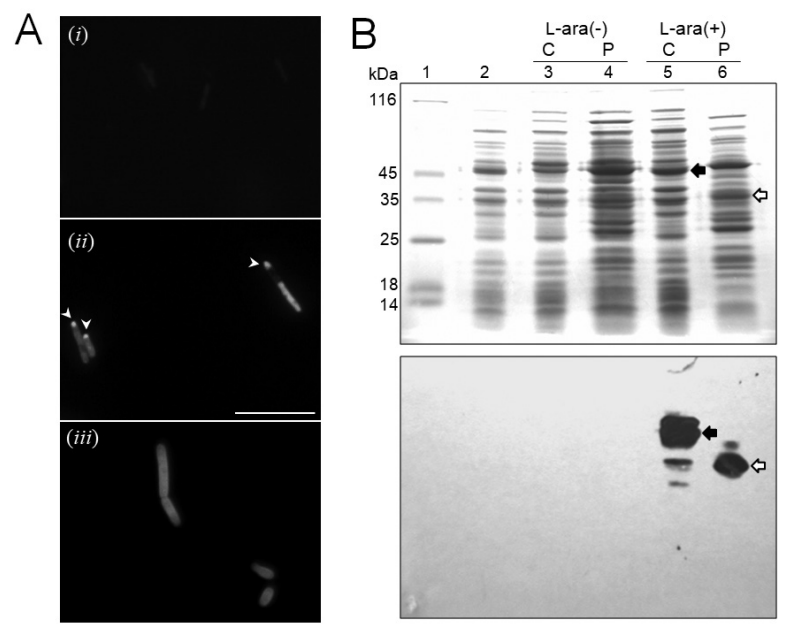

Figure 2. Tat translocation of TorAss-R.EcoRI $\Delta 71-277-G F P$ (TR'G) hybrid protein.

(A) Expression of the torAss-ecoRIR'-gfp fusion gene in E. coli DH5a carrying the pBadTR'G plasmid analyzed by fluorescence microscopy. A representative experiment is shown (i) pBadTR'G non-induced (exposed for $1.5 \mathrm{~ms}$ ), (ii) pBadTR'G induced for $2 \mathrm{~h}$ with $0.03 \%$ L-arabinose (exposed for $0.48 \mathrm{~ms}$ ), (iii) cells carrying pGreenTIR induced for $2 \mathrm{~h}$ with $0.1 \mathrm{mM}$ IPTG (exposed for 0.48 $\mathrm{ms}$ ). Arrowheads (panel ii) indicate pole-located protein aggregates. Scale bar: $5 \mathrm{~mm}$. (B) Subcellular distribution of TR'G protein analyzed by immunodetection with an anti-GFP serum, after cell fractionation. Top panel: visualization of the non-induced (lanes $2-4)$ or L-arabinose-induced $(0.03 \%$ for 2 h) (lanes 5 and 6) cell lysates after resolving on 10\% SDS-PAGE and staining with Coomassie Brilliant-Blue. Lane 1: size markers; lane 2: whole lysate from non-fractionated cells; lanes 3 and 5: cytoplasmic (C) fractions; lanes 4 and 6: periplasmic (P) fractions (six times more vol/ vol when compared to fraction C). Bottom panel: western blot analysis using mouse anti-GFP antibody. White arrows indicate the position of mature R.EcoRI $\Delta_{71-277}$ GFP (34.5 kDa), black arrows - the position of the TR'G pre-protein hybrid $(39.1 \mathrm{kDa})$.

at every stage of the transportation process (Santini et al., 2001; Thomas et al., 2001; DeLisa et al., 2002; Barrett et al., 2003). If the hybrid protein aggregates in inclusion bodies, GFP is not able to fluoresce because of its unfolded state (Waldo et al., 1999). Preliminary studies were performed with exponentially growing $\mathrm{DH} 5 \alpha$ bacteria carrying the pBadTR'G plasmid, after $1-h$ induction with $0.03 \%$ L-arabinose (Fig. 2). Subsequent fluorescence microscopy analysis of the cells showed that despite a rather gentle induction of expression, a pole-located aggregation of the hybrid protein could be observed, which did not happen in the case of native, non-transported GFP in the control cells (Fig. 2A(ii) and 2A(iii), respectively), which is in agreement with recently reported observation (Santini et al., 2001). Apart from the aggregation, high level of R.EcoRI $\Delta_{71-277}-$ GFP hybrid fluorescence was observed. Western blot analysis with an anti-GFP antibody demonstrated the full functionality of the Tat-mediated system both in exporting the native hybrid and in posttranslational modification (Fig. 2B, bottom). It is well known that GFP protein is incapable of folding into an active conformation in the periplasm (Feilmeier et al., 2000), so detectable fluorescence indicates that these hybrid folding could only take place in the cytoplasm. This was confirmed by the fact that the pre-protein was visible in the spheroplast fraction, but the mature-size $34.8 \mathrm{kDa}$ product of the $\mathrm{R}$. EcoRI $\Delta_{71-277}$-GFP fusion was found predominantly in the periplasmic fraction (Fig. 2B bottom, lane 6), with its increase after modification by the signal peptidase (Auclair et al., 2012). Since the hybrid with the N-terminal part of R.EcoRI was successfully transported across the mem-

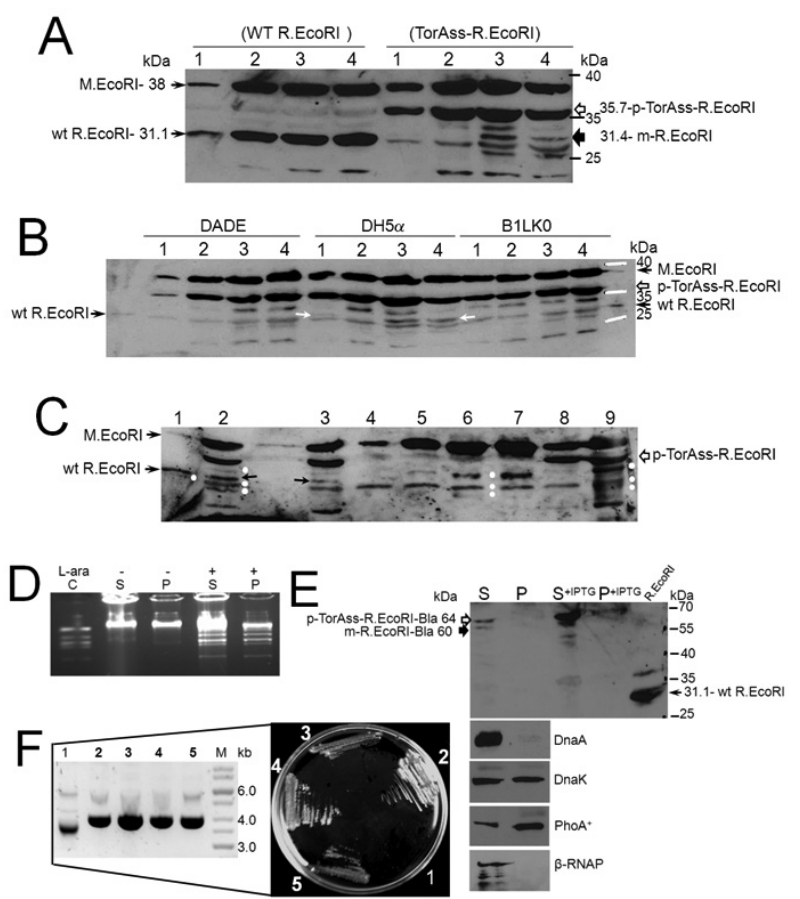

Figure 3. Export of the EcoRI endonuclease fused to the TorAss signal sequence.

(A) The dynamics of the expression of the wild-type R.EcoRIR (pBAD-RM) and hybrid TorAssR.EcoRI (pBadTRM) proteins in DH5a cells after 1, 2, 3, and 4-hour induction with $0.04 \%$ of L-arabinose. The same induction conditions were applied for all experiments described below. Western blot analysis performed using anti-M. EcoRI and anti-R.EcoRI antibodies. (B) Detection of the mature form of TorAssR.EcoRI by comparison of the lysates from the Tat transport defective cells (DADE and B1LK0) after 4-hour expression. White arrow - position of the mature R.EcoRI. (C) Detection of the mature form of TorAssR.EcoRI by comparison of lysates from cells producing EcoRI methylase alone. Lane 1: lysate of cells producing wild-type EcoRI R-M (pBAD-RM), five times diluted; lanes 2 and 3: lysates of the DH5a cells expressing the TorAssR. EcoRI (pBadTRM) overnight and after 4-hour induction, respectively; lanes 4-7: lysates of EcoRI methylase-producing cells (pBADM) after 1, 2, 3 and 4 hours of induction; lanes 8 and 9: lysates of $\Delta$ tatC cells (B1LK0) expressing the TorAssR.EcoRI hybrid, after 4-hour and overnight induction, respectively. White dots indicate EcoRI methyltransferase degradation products. Black arrow shows the position of the mature hybrid. (D) Restriction activity present in the spheroplast $(S)$ and periplasmic $(P)$ fraction of the cells, before (-) and after (+) L-arabinose induction of the cells carrying pBadTRM plasmid. $0.4 \mu \mathrm{g}$ of $\lambda$ DNA was digested for 1.5 hours with $3 \mu \mathrm{l}$ of cell extracts after fractionation. (E) Western blot analysis of fractionated extracts from cells expressing TorAss-R.EcoRI- $\beta$ lactamase (pSALectEcoRIR). +IPTG - indicates following fractions: spheroplast $(S)$ and periplasmic $(P)$ after 1 -h induction with $1 \mathrm{mM}$ IPTG. Arrows show the pre-protein $(p)$ and mature $(m)$ form of the hybrid. DnaA, DnaK, alkaline phosphatase $\left(\mathrm{PhoA}^{+}\right)$and $\beta$ subunit of the E. coli RNA polymerase ( $\beta$-RNAP) are shown as spheroplast/ periplasmic markers. (F) Right panel: Bglll restriction analysis of pSALectEcoRI recombinant DNA on $0.8 \%$ agarose gel. Positive recombinants (\#2-5 in bold) were linearized (4.03 kb). Inverted colors of the gel are shown. Left panel: The ampicillin resistant phenotype of the positive recombinants (\#2-5) bearing the pSALectEcoRI plasmid on $\mathrm{Ap}^{+}$selective medium after 48 -h growth at $37^{\circ} \mathrm{C}$. Negative recombinant is indicated as \#1.

brane, it was a promising indication for further experiments with the TorAss-R.EcoRI full-length hybrid.

\section{The effectiveness of phage DNA restriction by the endonuclease translocated into the periplasmic space}

The periplasmic localization of the EcoRI $\Delta_{71-277^{-}}$ GFP hybrid demonstrated by a fractionation assay and subsequent immunodetection with an anti-GFP serum 
(Fig. 2C), seemed promising in terms of continuing our studies in applying the Tat-mediated transport to the full-length endonuclease. Therefore, in order to test the functionality of the Tat-pathway secretion and DNA restriction, the pBad-TRM plasmid encoding both ss'TorA-R.EcoRI endonuclease and the EcoRI methyltransferase was constructed. Western blot analysis revealed that the expression of the fusion gene led to a high production of TorAss-R.EcoRI and its accumulation in the cytoplasm in both $\mathrm{Tat}^{+}$(DH5 $\left.\alpha\right), \Delta$ tatC (B1LK0) and $\triangle$ tat $A B C D(\mathrm{DADE})$ mutant strain (Fig. $3 \mathrm{~A}$ and $3 \mathrm{~B}$ ). While the cytoplasmic level of the TorAss-R.EcoRI precursor was not reduced in the tat deficient mutants when comparing to the wild-type strain (Fig. 3B), we could not see the mature form of EcoRI endonuclease in those cases. Most of immunospecific protein fragments observed on the gel were the results of methyltransferase protein degradation (Fig. 3C). Relatively little mature R.EcoRI was observed in the case of $\mathrm{Tat}^{+}$cells after the induction of expression (Fig. 3A, B, C). The quantification revealed that the mature endonuclease constituted only $3.5 \%$ of the whole. We determined the presence of mature R.EcoRI protein in the lysate of pBadTR-bearing M.EcoRI+ cells after ion-exchange chromatography on phosphocellulose (P11 column) (Supplementary Fig. 2 at https://ojs.ptbioch.edu.pl/index.php/abp). Proteins bound to the column were eluted with a linear gradient of 0.02-1.0 M KCl. Then, fractions were assayed for endonuclease activity using phage lambda DNA. We found two peaks of endonucleolytic activity: a weak (fractions \#20-26) and a strong one (fractions \#50-59) (Supplementary Fig. 2A). The fractions with weak activity contained the pre-protein which was vulnerable to proteolytic degradation, whereas fractions with high and specific activity contained a stable, mature R.EcoRI of about $31.2 \mathrm{kDa}$, co-migrating with the wild-type control $(30.08$ $\mathrm{kDa}$ ) (Supplementary Fig. 2 B, C at https://ojs.ptbioch. edu.pl/index.php/abp). The specific EcoRI endonuclease activity was detected in both cellular fractions (Fig. 3D). As described earlier, usually, the translocation of the recombinant Tat substrates is not complete, therefore the precursor as well as the mature-sized proteins may accumulate in the cytoplasm (Blaudeck et al., 2001; Sturm et al., 2006; Richter et al., 2007). The $\lambda_{\text {vir }}$ phage DNA restriction assay demonstrated that cells exhibited a restriction activity level 10 times higher than in case of the restriction-negative control strain. We found that the transportation outcome was not limited by the degradation in the periplasmic space. We did not observe an increased export in the HM140 strain deficient in known cell envelope proteases (DegP, protease III (Ptr), Tsp, Eda and OmpT) as well as the rpoH15 mutant allele (Supplementary Fig. 3, lanes 1-2 vs. lanes 5-6 at https://ojs.ptbioch.edu.pl/index.php/abp) (Meerman \& Georgiou, 1994). However, as already shown, the rate of phage DNA transport across bacterial membranes varied was rather high and reached a value several-fold higher when compared to conjugation or transformation processes (Letellier et al., 1999). Moreover, the transferred DNA crosses the bacterial envelope linearly through the protein/lipid channel, therefore, it is protected from the periplasmic nucleases (Letellier et al., 2003) (Roessner and Ihler, 1986). Different forms of DNA channels created with the participation of phage proteins concern both T-odd (T3, T5, T7) and T-even (T4) phages (Letellier et al., 1999). Probably for this reason there is no noticeable effect of periplasmic DNase endonuclease I presence on the effectiveness of phage lambda infection (Dürwald \& Hoffmann-Berling, 1968). However, early experiments on T-phage series showed that DNA degradation appeared to be mediated by endonuclease I only during superinfection in conjunction with temporal exclusion phenomenon, the phage-induced inhibition of DNA penetrating the cell envelope (Fielding \& Lunt, 1970; Anderson \& Eigner, 1971). Another aspect is that most of phages choose the cellular poles of Gram-negative bacteria as the preferred place for DNA injection, which can possibly limit its contact with periplasmic nucleases (Edgar et al., 2008).

Since the Tat components are present at relatively low levels in E. coli cells, we tried to co-express the tat $A B C$ genes (pEXT-TatABCs plasmid) to reinforce the flux by this secretion pathway (Barrett et al., 2003) As shown in Supplementary Fig. 3 (at https://ojs.ptbioch.edu.pl/ index.php/abp) this did not increase the export capacity under the applied conditions in comparison to the wild-type Tat levels ( $4 \mathrm{~h}$ and overnight, lanes 3 and 4 vs. lanes 5 and 6 , respectively). There are two difficulties in transporting this cytoplasmic endonuclease across the membrane. Firstly, the likely saturation of the Tat pathway by increasing production of TorAss-R.EcoRI; secondly, the protein instability. We observed a high level of stable pre-protein in the cytoplasm and only a few percent of mature protein after the transport. Our hybrid proteins exhibited most, if not all, of their restriction activity in the cytoplasm. We found that the transportation outcome was not limited by the degradation process in the periplasmic space. We did not observe an increase of export in the HM140 strain deficient in known cell envelope proteases (Supplementary Fig. 3 at https://ojs. ptbioch.edu.pl/index.php/abp) (Gentz et al., 1988; Meerman \& Georgiou, 1994).

\section{Tat-dependent translocation of the hybrid R.EcoRI with pSALect vector}

To get a clear answer about the Tat-dependent R.EcoRI endonuclease export across the membrane, we used a pSALect vector-based system employing an $\mathrm{N}$ terminal TorAss leader which directs the post-translational export of the fusion protein with a C-terminally fused $\beta$-lactamase (Bla) reporter, to the periplasm (Lutz et al., 2002). The Bla protein is only functional when it is translated in-frame with the target protein and only after its translocation across the inner membrane to the periplasm where disulfide bond formation takes place. Thus, the pSALectEcoRI plasmid was constructed, which encoded the TorAss-R.EcoRI-Bla hybrid. Such construct can only be maintained in cells with the presence of the pIM27Tc plasmid serving as the source of M.EcoRI methyltransferase, whose gene is constitutively expressed from its own promoter (Mruk et al., 2011). It was shown that only positive recombinants with the endonuclease/ $\beta$-lactamase hybrid transported across the membrane were able to grow on LB-agar plates containing $50 \mu \mathrm{g} / \mathrm{ml}$ ampicillin even without IPTG induction of the gene expression (Fig. 3F). $\beta$-lactam resistance phenotype testified conclusively to the fact that the transport of the R.EcoRI- $\beta$-lactamase hybrid into the periplasm occurred, but western blot analysis of the IPTG-induced cell lysates revealed its very low efficiency. The presence of the immature hybrid was observed mainly in the cytoplasmic fraction after cell fractionation (Fig. 3E). EcoRI endonuclease activity was detected in both fractions after $0.1 \mathrm{mM}$ IPTG induction (data not shown). This indicates that R.EcoRI protein is an appropriate target for export by the Tat system. In parallel, we monitored the protein markers of the cytoplasmic fraction, i.e. replica- 
tion factors DnaA and DnaK (a significant fraction of this chaperone can be released outside the cell by osmotic shock, (el Yaagoubi et al., 1994), a transcriptional machinery protein - the $\beta$-subunit of the RNA polymerase and a periplasmic protein - alkaline phosphatase, PhoA (Fig. 3E).

\section{Signal recognition particle (SRP) co-translational export of DsbAssR.EcoRI hybrid}

In order to direct R.EcoRI to the SRP pathway we fused it to the DsbA protein signal sequence of $E$. coli (periplasmic disulfide bond oxidoreductase) (Schierle et al., 2003). This co-translational translocation would prevent the formation of a secondary structure and therefore precluded enzyme's activity in the cytoplasm. E. coli ER1992 cells carrying pBADdsbRM construct (Fig. 1) after L-arabinose induction accumulated high amount of pre-DsbAssR.EcoRI hybrid protein but the efficiency of the export to the periplasm was very low (Supplementary Fig. 4A at https://ojs.ptbioch.edu.pl/index. php/abp). Although EcoRI restriction activity could be easily detected in cell extracts (Supplementary Fig. 4B at https://ojs.ptbioch.edu.pl/index.php/abp), the ability of those cells to restrict lambda phage DNA was almost none (Supplementary Fig. 4C). Using phosphocellulose chromatography fractionation we showed that pre-DsbAssREcoRI protein had EcoRI-specific restriction activity (Supplementary Fig. 4D at https://ojs.ptbioch.edu. $\mathrm{pl} /$ index.php/abp) suggesting it underwent of proper folding in the cytoplasm. However, the overproduction of the hybrid precursor did not induce SOS response (Supplementary Fig. 4E, F at https://ojs.ptbioch.edu.pl/ index.php/abp).

Analyzing expression of the ecoRIR and ecoRIM from the pBadTRM plasmid which depends on the arabinose promoter, we observed an equal and high level of endonuclease and methyltransferase production, which did not allow the efficient restriction of the phage DNA. Thus, we tried to separate the R-M gene expression control by employing a two-plasmid system, maintaining a constitutive expression of the EcoRI methyltransferase gene from its natural $\mathrm{P}_{\mathrm{R}}$ promoter ( $\mathrm{pACYC} \Delta \mathrm{eco}$ plasmid), and having an arabinose-inducible torAss/endonuclease fusion gene (pBadTR). By induction with $0.03 \%$ $\mathrm{L}$-arabinose we were able to increase the DNA restriction to the same level as in the case of the pBAD-RM plasmid, but not higher (Supplementary Table 2 at https://ojs.ptbioch.edu.pl/index.php/abp). This was most probably limited due to the excess of cellular restriction over methylation which caused a cell survival problem (Naito et al., 1995) manifested by growth inhibition and loss of the pBadTR plasmid (data not shown).

\section{CONCLUSIONS}

Collectively, our results suggest that restriction endonuclease may not be a suitable tool for restriction of foreign DNA in the periplasmic space. The key problem in this case is jamming of the Tat translocation machinery and also lack of optimal conditions for DNA restriction in the periplasm. Low endonuclease concentration in the periplasm caused omission the DNA target (number of infected phages per cell was limited up to several per cell under the applied conditions), or lack of access to the target DNA (phage DNA sheltered by tail and/or phage proteins creating the channel).

\section{Conflicts of interest}

The authors declare no conflict of interest.

\section{Acknowledgements}

The authors are very grateful to Prof. I. Kobayashi (University of Tokyo) for the anti-R.EcoRI and -M.EcoRI antibodies and to Dr. A. Herman-Antosiewicz, Dr. M. Glinkowska and Dr. J. Skorko-Glonek (University of Gdansk) for sera against GFP, DnaK, DnaA, RpoB and PhoA, respectively. Also, we are very thankful to Dr. G. Buchanan (University of Dundee) for the DADE and B1LK0 E. coli strains, to Prof. S. Lutz (Emory University) for the pSALect vector, and to Prof. C. Robinson (University of Kent) for the pETX22_ $\mathrm{ABC}_{\text {Strep }}$ plasmid.

\section{Supplementary material}

All Supplementray materials are at https://ojs.ptbioch. edu.pl/index.php/abp

\section{REFERENCES}

Anderson CW, Eigner J (1971) Breakdown and exclusion of superinfecting T-even bacteriophage in Escherichia coli. J Virol 8: 869-886. PMC376278

Auclair SM, Bhanu MK, Kendall DA (2012) Signal peptidase I: cleaving the way to mature proteins. Protein Sci 21: 13-25. https://doi. org/10.1002/pro. 757

Barrett CM, Ray N, Thomas JD, Robinson C, Bolhuis A (2003) Quantitative export of a reporter protein GFP by the twin-arginine translocation pathway in Escherichia coli. Biochem Biophys Res Commun 304: 279-284. https://doi.org/10.1016/S0006-291X(03)00583-7

Blaudeck N, Sprenger GA, Freudl R, Wiegert T (2001) Specificity of signal peptide recognition in tat-dependent bacterial protein translocation. J Bacteriol 183: 604-610. https://doi.org/10.1128/ JB.183.2.604-610.2001

Bogsch EG, Sargent F, Stanley NR, Berks BC, Robinson C, Palmer T (1998) An essential component of a novel bacterial protein export system with homologues in plastids and mitochondria. J Biol Chem 273: 18003-18006. https://doi.org/10.1074/jbc.273.29.18003

Brüser T (2007) The twin-arginine translocation system and its capability for protein secretion in biotechnological protein production. Appl Microbiol Biotechnol 76: 35-45. https://doi.org/10.1007/s00253007-0991-z

DeLisa MP, Samuelson P, Palmer T, Georgiou G (2002) Genetic analysis of the twin arginine translocator secretion pathway in bacteria. J Biol Chem 277: 29825-29831. https://doi.org/10.1074/jbc. M201956200

Dürwald H, Hoffmann-Berling H (1968) Endonuclease-I-deficient and ribonuclease I-deficient Escherichia coli mutants. J Mol Biol 34: 331346. https://doi.org/10.1016/0022-2836(68)90257-X

Edgar R, Rokney A, Feeney M, Semsey S, Kessel M, Goldberg MB, Adhya S, Oppenheim AB (2008) Bacteriophage infection is targeted to cellular poles. Mol Microbiol 68: 1107-1116. https://doi. org/10.1111/j.1365-2958.2008.06205.x

el Yaagoubi A, Kohiyama M, Richarme G (1994) Localization of DnaK (chaperone 70) from Escherichia coli in an osmotic-shocksensitive compartment of the cytoplasm. J Bacteriol 176: 7074-7078. https://doi.org/10.1128/jb.176.22.7074-7078.1994

Feilmeier BJ, Iseminger G, Schroeder D, Webber H, Phillips GJ (2000) Green fluorescent protein functions as a reporter for protein localization in Escherichia coli. J Bacteriol 182: 4068-4076. https://doi. org/10.1128/JB.182.14.4068-4076.2000

Fielding PE, Lunt MR (1970) The relation between breakdown of superinfecting virus deoxyribonucleic acid and temporal exclusion induced by T4 and T5 bacteriophages. J Gen Virol 6: 333-342. https://doi.org/10.1099/0022-1317-6-3-333

Fomenkov A, Xiao JP, Dila D, Raleigh E, Xu SY (1994) The 'endoblue method' for direct cloning of restriction endonuclease genes in E. coli. Nucleic Acids Res 22: 2399-2403. PMC523701

Gentz R, Kuys Y, Zwieb C, Taatjes D, Taatjes H, Bannwarth W, Stueber D, Ibrahimi I (1988) Association of degradation and secretion of three chimeric polypeptides in Escherichia coli. J Bacteriol 170: 2212-2220. https://doi.org/10.1128/jb.170.5.2212-2220.1988

Grant SG, Jessee J, Bloom FR, Hanahan D (1990) Differential plasmid rescue from transgenic mouse DNAs into Escherichia coli methylation-restriction mutants. Proc Natl Acad Sci USA 87: 4645-4649. https://doi.org/10.1073/pnas.87.12.4645 
Guzman LM, Belin D, Carson MJ, Beckwith J (1995) Tight regulation modulation and high-level expression by vectors containing the arabinose PBAD promoter. J Bacteriol 177: 4121-4130. https://doi. org/10.1128/jb.177.14.4121-4130.1995

Harrison JS, Keshavarz-Moore E, Dunnill P, Berry MJ, Fellinger A, Frenken L, 1997. Factors affecting the fermentative production of a lysozyme-binding antibody fragment in Escherichia coli. Biotechnol Bioeng 53: 611-622. https://doi.org/10.1002/(SICI)10970290(19970320)53:6<611::AID-BIT9>3.0.CO;2-P

Holubova I, Vejsadova S, Weiserova M, Firman K (2000) Localization of the type I restriction-modification enzyme EcoKI in the bacterial cell. Biochem Biophys Res Commun 270: 46-51. https://doi. org/10.1006/bbrc.2000.2375

Kellenberger G, Zichichi ML, Weigle J (1960) Mutations affecting the density of bacteriophage $\lambda$. Nature 187: 161-162. https://doi. org/10.1038/187161a0

Kohring GW, Mayer F (1987) In situ distribution of EcoRI methylase and restriction endonuclease in cells of Escherichia coli Bs 5. FEBS Lett 216: 207-210. https://doi.org/10.1016/0014-5793(87)80690-7

Kudva R, Denks K, Kuhn P, Vogt A, Muller M, Koch HG (2013) Protein translocation across the inner membrane of Gram-negative bacteria: the Sec and Tat dependent protein transport pathways. Res Microbiol 164: 505-534. https://doi.org/10.1016/j.resmic.2013.03.016

Labrie SJ, Samson JE, Moineau S (2010) Bacteriophage resistance mechanisms. Nat Rev Microbiol 8: 317-327. https://doi.org/10.1038/ nrmicro2315

Letellier L, Boulanger P, de Frutos M, Jacquot P (2003) Channeling phage DNA through membranes: from in vivo to in vitro. Res Microbiol 154: 283-287. https://doi.org/10.1016/S0923-2508(03)00072-X

Letellier L, Plançon L, Bonhivers M, Boulanger P (1999) Phage DNA transport across membranes. Res Microbiol 150: 499-505. https://doi. org/10.1016/S0923-2508(99)00107-2

Lutz S, Fast W, Benkovic SJ (2002) A universal vector-based system for nucleic acid reading-frame selection. Protein Eng 15: 1025-1030. https://doi.org/10.1093/protein/15.12.1025

Makarova KS, Wolf YI, Koonin EV (2013) Comparative genomics of defense systems in archaea and bacteria. Nucleic Acids Res 41: 43604377. https://doi.org/10.1093/nar/gkt157

Matos CF, Branston SD, Albiniak A, Dhanoya A, Freedman RB, Keshavarz-Moore E, Robinson C (2012) High-yield export of a native heterologous protein to the periplasm by the tat translocation pathway in Escherichia coli. Biotechnol Bioeng 109: 2533-2542. https://doi. org/10.1002/bit.24535

Meerman HJ, Georgiou G (1994) Construction and characterization of a set of E. coli strains deficient in all known loci affecting the proteolytic stabdoiility of secreted recombinant proteins. Biotechnology (N Y) 12: 1107-1110. https://doi.org/10.1038/nbt1194-1107

Mejean V, Iobbi-Nivol C, Lepelletier M, Giordano G, Chippaux M, Pascal MC (1994) TMAO anaerobic respiration in Escherichia coli: involvement of the tor operon. Mol Microbiol 11: 1169-1179. https:// doi.org/10.1111/j.1365-2958.1994.tb00393.x

Mergulhao FJ, Summers DK, Monteiro GA (2005) Recombinant protein secretion in Escherichia coli. Biotechnol Adv 23: 177-202. https:// doi.org/10.1016/j.biotechadv.2004.11.003

Miller WG, Lindow SE (1997) An improved GFP cloning cassette designed for prokaryotic transcriptional fusions. Gene 191: 149-153. https://doi.org/10.1016/S0378-1119(97)00051-6

Mruk I, Liu Y, Ge L, Kobayashi I (2011) Antisense RNA associated with biological regulation of a restriction-modification system. $\mathrm{Nu}$ cleic Acids Res 39: 5622-5632. https://doi.org/10.1093/nar/gkr166

Naito T, Kusano K, Kobayashi I (1995) Selfish behavior of restrictionmodification systems. Science 267: 897-899. https://doi.org/10.1126/ science. 7846533
Pleška M, Qian L, Okura R, Bergmiller T, Wakamoto Y, Kussell E, Guet CC (2016) Bacterial autoimmunity due to a restriction-modification system. Curr Biol 26: 404-409. https://doi.org/10.1016/j. cub.2015.12.041

Richter S, Lindenstrauss U, Lucke C, Bayliss R, Bruser T (2007) Functional Tat transport of unstructured small hydrophilic proteins. J Biol Chem 282: 33257-33264. https://doi.org/10.1074/jbc.M703303200

Roessner CA, Ihler GM (1986) Formation of transmembrane channels in liposomes during injection of lambda DNA. J Biol Chem 261: 386-390. PMID:2416751

Sambrook J, Fritsch EF, Maniatis T (1989) Molecular Cloning: A Laboratory Manual. 2nd edn. Cold Spring Harbor New York: Cold Spring Harbor Laboratory Press. ISBN:0879693096

Samson JE, Magadan AH, Sabri M, Moineau S (2013) Revenge of the phages: defeating bacterial defences. Nat Rev Microbiol 11: 675-687. https://doi.org/10.1038/nrmicro3096

Santini CL, Bernadac A, Zhang M, Chanal A, Ize B, Blanco C, Wu LF (2001) Translocation of jellyfish green fluorescent protein via the Tat system of Escherichia coli and change of its periplasmic localization in response to osmotic up-shock. J Biol Chem 276: 8159-8164. https://doi.org/10.1074/jbc.C000833200

Santini CL, Ize B, Chanal A, Muller M, Giordano G, Wu LF (1998) A novel sec-independent periplasmic protein translocation pathway in Escherichia coli. EMBO J 17: 101-112. https://doi.org/10.1093/ emboj/17.1.101

Sargent F, Bogsch EG, Stanley NR, Wexler M, Robinson C, Berks BC, Palmer T (1998) Overlapping functions of components of a bacterial Sec-independent protein export pathway. EMBO J 17: 3640-3650. https://doi.org/10.1093/emboi/17.13.3640

Schierle CF, Berkmen M, Huber D, Kumamoto C, Boyd D, Beckwith J (2003) The DsbA signal sequence directs efficient cotranslational export of passenger proteins to the Escherichia coli periplasm via the signal recognition particle pathway. J Bacteriol 185: 5706-5713. https://doi.org/10.1128/JB.185.19.5706-5713.2003

Sturm A, Schierhorn A, Lindenstrauss U, Lilie H, Bruser T (2006) YcdB from Escherichia coli reveals a novel class of Tat-dependently translocated hemoproteins. J Biol Chem 281: 13972-13978. https:// doi.org/10.1074/jbc.M511891200

Thomas JD, Daniel RA, Errington J, Robinson C (2001) Export of active green fluorescent protein to the periplasm by the twin-arginine translocase (Tat) pathway in Escherichia coli. Mol Microbiol 39: 47-53. http://dx.doi.org/10.1046/j.1365-2958.2001.02253.x

Tock MR, Dryden DT (2005) The biology of restriction and anti-restriction. Curr Opin Microbiol 8: 466-472. https://doi.org/10.1016/j. mib.2005.06.003

Toksoy E, Ozdinler PH, Onsan ZI, Kirdar B (1999) High level secretion of TaqI restriction endonuclease by recombinant Escherichia coli. Biotechnology Techniques 13: 803-808. https://doi. org/10.1023/A:1008938302312

Toksoy E, Onsan ZI, Kirdar B (2001) Effect of the co-expression of methyltransferase activity on extracellular production of TaqI restriction endonuclease in recombinant E. coli cells. Process Biochemistry 37: 527-534. https://doi.org/10.1016/S0032-9592(01)00231-X

Waldo GS, Standish BM, Berendzen J, Terwilliger TC (1999) Rapid protein-folding assay using green fluorescent protein. Nat Biotechnol 17: 691-695. https://doi.org/10.1038/10904

Wexler M, Sargent F, Jack RL, Stanley NR, Bogsch EG, Robinson C, Berks BC, Palmer T (2000) TatD is a cytoplasmic protein with DNase activity. No requirement for TatD family proteins in secindependent protein export. J Biol Chem 275: 16717-16722. https:// doi.org/10.1074/jbc.M000800200 